\title{
Heavy metal fractionation studies in tidal sediment cores in the clam farms from Tan Thanh commune, Go Cong dong district, Tien Giang province, Vietnam
}

\author{
Nghiên cứu về hàm lượng kim loại nặng tồn tại dưới các dạng liên kết trong mẫu lõi trầm tích \\ bãi nuôi nghêu xã Tân Thành, huyện Gò Công đông, tỉnh Tiền Giang, Việt Nam
}

\author{
NGUYEN, Mai Lan \\ Institute of the Geological Sciences, Vietnam Academy of Science and Technology, 84 Chua Lang Str., Dong Da, Hanoi, Vietnam
}

\begin{abstract}
This paper introduces the results from a study on the distribution of heavy metals in chemical fractions in tidal sediment cores at four sample stations inside the baby clam breeding plain, inside the harvested clam breeding plain, and on the frontier between the plains in the clam farms in Tan Thanh commune, Go Cong Dong district, Tien Giang province, Vietnam. The partitioning of metals among the compartments of the sediment's solid phase was investigated indirectly by selective sequential extraction of substances that are water-soluble, exchangeable, bound to carbonates, bound to Mn oxides, bound to amorphous Fe oxides, bound to crystalline Fe oxides, associated with organics and residual. In case of investigated heavy metals (HM), the concentrations of $\mathrm{Zn}$ and $\mathrm{Hg}$ exceeded the National Technical Regulation on Sediment Quality QCVN 43:2012/BTNMT by 1.12 - 3.53 times and 26.58 - 171.96 times, respectively. The highest HMs concentration was found in the oxidable fraction (more than 60\%). The data demonstrates the important role of organic matters in the oxidable condition at the surficial sediment layer. Besides the oxidable fraction, high HMs concentrations were measured also in the residual fraction. The HMs content present in the solid residue also indicates the level of contamination in the river system: the greater the percentage of HMs present in the solid residue, the lesser the pollution in the environment because this solid residue involves components that can not be remobilized. The HMs concentrations depending on the depth of the sediment indicate that clam's digestive activity or the decomposition of tissue and shell of clams possibly affects the content of HMs.
\end{abstract}

\begin{abstract}
Bài báo giới thiệu các kết quả nghiên cứu về sự phân bố kim loại nặng dưới các dạng liên kết khác nhau trong các mẫu lõi trầm tích tại các bãi nuôi nghêu giống, bãi nuôi nghêu sau khi đã thu hoạch, và ranh giới giữa các bãi nuôi nghêu tại xã Tân Thành, huyện Gò Công Đông, tỉnh Tiền Giang, Việt Nam. Các dạng pha liên kết bao gồm: 1.pha hòa tan; 2. pha trao đổi; 3.liên kết với các bô nát; 4. liên kết với Man gan ô xit; 5. liên kết với sắt ô xít vô định hinh; 6. liên kết với sắt ô xít dạng tinh thể; 7. liên kết với thành phần hữu cơ và; 8. Phần bã rắn. Trong các kim loại nặng (KLN) được phân tích, hàm lượng Zn và Hg vượt quá tiêu chuẩn cho phép QCVN 43:2012/BTNMT lần lượt từ 1,12 - 3,53 và 24,58 - 171,96 lần. Hàm lượng KLN tồn tại nhiều nhất dưới dạng liên kết với các thành phần có khả năng ô xi hóa với tỉ lệ hơn 60\% chỉ ra vai trò của thành phần hữu cơ trong điều kiện ô xi hóa tại lớp trầm tích tầng mặt. Sau các thành phần có khả năng ôxi hóa, các KLN hiện diện trong phần bã rắn nhiều hơn trong các pha khác. Sự có mặt của KLN trong phần bã rắn chỉ ra mức độ ô nhiễm của hệ thống sông: càng nhiều phần trăm KLN có mặt trong phần bã rắn, càng it ô nhiếm trong môi trường bởi phần bã rắn này liên quan đến các thành phần không thể bị rửa tách. Sự phụ thuộc theo độ sâu của hàm lượng kim loại nặng đưa ra khả năng về sự ảnh hưởng của hoạt động tiêu hóa và quá trình phân hủy của nghêu lên hàm lượng kim loại nặng.
\end{abstract}

KEYWORDS: heavy metals, core sediments, fraction, clam breeding, sequential extraction, Tien Giang

\section{Introduction}

Vietnam ranks the third after China and India in the aquaculture industry and has been growing strongly since 2003. With a coastline of more than 3,200 km long with over 3,000 islands, a wealth of natural inland water bodies (lakes and rivers) and seasonally flooded grounds, since 2000, the fisheries sector is an important contributor to the economy of Vietnam and fisheries are identified as a key economic growth sector by the Vietnamese Government (MOFI, 2006Seventy percent of coastal aquaculture production of Vietnam occurs in the southern area, in the Mekong River Delta (MOFI, 2006). With over 700 km of coastline, the coastal aquaculture of the Mekong River Delta has been well known for the farming of marine shrimps and mollusks. However, in the past few years, the phenomenon of widespread mass clam deaths had occurred in this Delta (Zing (2013), Nhan Dan (2011), Bao Moi (2013), Nong 
Nghiep (2010). Following an initial inspection by the provincial fisheries department, salinity and temperature at the clam farms are believed to be meeting standards, so environmental pollution was suspected to be the cause.

As a complex and dynamic aquatic environment (Morris et al. 1995), the estuarine and coastal environment is affected by anthropogenic input pollutants. Among the pollutants getting into these environments, heavy metals (HMs) are some of the major indicators to assess the environmental pollution. Most of the HMs cannot be biologically or chemically degraded. They may be accumulated locally or be transported over long distances. The majority of HMs is persistent and can accumulate in sediments or are prone to bioaccumulate (Salomons and Forstner, 1984). Heavy metal accumulation in sediment can have an effect on the ecosystem due to its easy entering to the food chain and bioaccumulation (Beijer and Jernelov, 1986). Especially bivalve mollusks as clams use sediment as a food source; therefore, they could accumulate HMs in their tissue. As a result, the assessment of heavy metal contamination in surficial sediment plays an important role in environmental quality control because of their toxic, non - degradable ability and their bioaccumulation (Vollenweider et al., 1996).

Chemical speciation can be defined as the identification and quantification of the different chemical species, forms or phases present in the sediment as well as in other environments. However, the determination of specific chemical species is difficult and often hardly possible (Loska and Wiechula, 2002). HMs are associated with sediments in different ways, and the association determines their mobility and availability (Ahumuda et al., 1999). Water soluble and exchangeable forms are considered readily mobile and available to fauna and flora, while metals incorporated in the crystalline lattice of sediments appear relatively inactive. The other forms like carbonate-bound, occlusion in $\mathrm{Fe}, \mathrm{Mn}$ and $\mathrm{Al}$ oxides, or complexes with $\mathrm{OM}$ and Fe-Mn oxides have been found to be the most important components, which influence the media to long-term effect and availability (lyengar et al., 1981). The potential of bioaccumulation of metals can be evaluated by studying the sediments and also by assessing the possible toxicity or risk of environmental pollution due to the presence of HMs in sediments. Different types of association between metals and the sediments can be understood in detail by sequential extraction techniques. Conceptually, the solid materials can be partitioned into a specific fraction, which can be extracted selectively by using appropriate reagents. The use of sequential extraction, although more time consuming, furnishes detailed information about the origin, mode of occurrence, biological and physicochemical availability, mobilization and transport of metals. Leleyter and Probst (1999) developed a new seven-step procedure to determine the speciation of various trace elements, which is an improvement of the methodology developed by Teisser et al. (1979) and Schuman (1985).
The aim of the present study is to investigate different chemical forms of HMs in sediments and to assess their association and bioavailability in the river.

\section{Materials and methods}

\subsection{Sampling site}

The Tan Thanh commune of Go Cong Dong district, Tien Giang province is located in the Mekong Delta region of $\mathrm{Vi-}$ etnam where famous clam farms are situated. The area selected for this study is between the Den Do hamlet and Tan Thanh resort (Figure 1) with a water area of about 2,000 hectares (ha) used for clam aquaculture. The elevation of this tidal area is from 0.6 to $-6.0 \mathrm{~m}$. The core sediments were collected using a gravity type sediment corer of a $1 \mathrm{~m}$ length of polycarbonate tube. Our research focuses on the $0.4 \mathrm{~m}$ above of core-length. The sampling stations include:

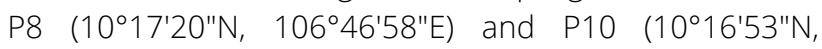
$\left.106^{\circ} 46^{\prime} 44^{\prime \prime} \mathrm{E}\right)$ inside the baby clam breeding plain; P9 $\left(10^{\circ} 17^{\prime} 06^{\prime \prime} \mathrm{N}, 106^{\circ} 46^{\prime} 52^{\prime \prime} \mathrm{E}\right)$ inside the harvested clam breeding plain; P11 (10¹6'38"N, 106 46'28"E) on the frontier between the plains (Figure 1). All samples were collected in April, during the dry season.

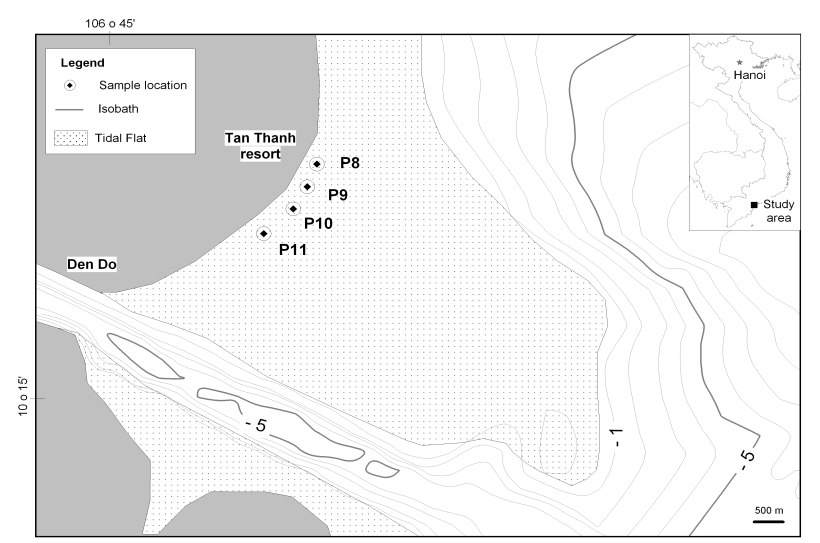

Figure 1 - Location of the sample stations in the research region - Tan Thanh, Go Cong Dong, Tien Giang

\subsection{Sampling and analysis}

This study focuses on the surficial sediment $(0-60 \mathrm{~cm})$ in a tidal wetland in the estuary Tieu, Tan Thanh, Go Cong Dong, Tien Giang, which is the sediment layer reflecting the historical pollution (Salomons and Forstner, 1984; Forstner, 1989). This layer is also the living environment of clams, which can grow, digest and die at the depth of 20 $\mathrm{cm}$. For this reason, the sediment cores were cut after collection in three slices: from 0 to $20 \mathrm{~cm}, 20$ to $40 \mathrm{~cm}$, and 40 to $60 \mathrm{~cm}$ of depth. The samples were stored in freeze room at $4^{\circ} \mathrm{C}$. At position Tan Thanh P11 (TT - P11), the core has just two slices (from 0 to $40 \mathrm{~cm}$ ) because the third one was damaged after cutting.

To measure the total HMs concentration in every slice, the sediment sample was digested following the method of Jarvis et al. (1992) by using acid mixture $\mathrm{HF} / \mathrm{HClO}_{4}$ and then 
$\mathrm{HNO}_{3}$ before being analysed by Inductively Coupled Plasma Spectrometer (ICP-MS, Ultramass-700) in the laboratory of the Institute of Geological Sciences (Vietnam Academy of Science and Technology).

\section{Table 1. Selective sequential extraction (SSE) procedure}

\begin{tabular}{|c|c|c|c|c|c|c|}
\hline$N^{0}$ & Fraction & Extractant & Vol. & Time & Temp. & $\mathrm{pH}$ \\
\hline $\mathrm{F} 1$ & Water soluble & deionized water & $10 \mathrm{ml}$ & $30 \mathrm{~min}$ & $20^{\circ} \mathrm{C}$ & \\
\hline $\mathrm{F} 2$ & Exchangeable & $1 \mathrm{M} \mathrm{Mg}\left(\mathrm{NO}_{3}\right)_{2}$ & $10 \mathrm{ml}$ & $2 \mathrm{~h}$ & $20^{\circ} \mathrm{C}$ & 5 with $\mathrm{HNO}_{3}$ \\
\hline F3 & Bound to carbonate & $1 \mathrm{M} \mathrm{NaCOOCH}_{3}$ & $10 \mathrm{ml}$ & $5 h$ & $20^{\circ} \mathrm{C}$ & 4.5 with $\mathrm{CH}_{3} \mathrm{COOH}$ \\
\hline F4 & Bound to $\mathrm{Mn}$ - O & $0,1 \mathrm{M} \mathrm{NH}{ }_{2} \mathrm{OH} . \mathrm{HCl}$ & $10 \mathrm{ml}$ & 30 min & $20^{\circ} \mathrm{C}$ & 3.5 with $\mathrm{HNO}_{3}$ \\
\hline F5 & $\begin{array}{l}\text { Bound to } \\
\text { amorphous Fe-O }\end{array}$ & $\begin{array}{l}0,2 \mathrm{M}\left(\mathrm{NH}_{4}\right)_{2} \mathrm{C}_{2} \mathrm{O}_{4} \cdot \mathrm{H}_{2} \mathrm{O}+0,2 \mathrm{M} \\
\mathrm{H}_{2} \mathrm{C}_{2} \mathrm{O}_{4} \cdot \mathrm{H}_{2} \mathrm{O}\end{array}$ & $10 \mathrm{ml}$ & $4 \mathrm{~h}$ & $\begin{array}{l}20^{\circ} \mathrm{C} \\
\text { (in dark) }\end{array}$ & 3 with $\mathrm{HNO}_{3}$ \\
\hline F6 & $\begin{array}{l}\text { Bound to } \\
\text { crystalline Fe-O }\end{array}$ & $\begin{array}{l}0.2 \mathrm{M}\left(\mathrm{NH}_{4}\right)_{2} \mathrm{C}_{2} \mathrm{O}_{4} \cdot \mathrm{H}_{2} \mathrm{O}+0,2 \mathrm{M} \\
\mathrm{H}_{2} \mathrm{C}_{2} \mathrm{O}_{4} \cdot \mathrm{H}_{2} \mathrm{O}+0,1 \mathrm{M} \mathrm{C}_{6} \mathrm{H}_{8} \mathrm{O}_{6}\end{array}$ & $10 \mathrm{ml}$ & $\begin{array}{l}30 \text { min } \\
\text { (in dark) }\end{array}$ & $80^{\circ} \mathrm{C}$ & 2.3 with $\mathrm{NO}_{3}$ \\
\hline F7 & $\begin{array}{l}\text { Oxidizable } \\
\text { or bound to organic }\end{array}$ & $\begin{array}{l}0.02 \mathrm{M} \mathrm{HNO}_{3}+30 \% \mathrm{H}_{2} \mathrm{O}_{2} \\
\text { then } 5 \mathrm{ml} 3.2 \mathrm{M} \mathrm{NH}_{4} \mathrm{COOCH}_{3}+\end{array}$ & $\begin{array}{l}3 \mathrm{ml} \\
8 \mathrm{ml}\end{array}$ & $5 h$ & $85^{\circ} \mathrm{C}$ & 2 with $\mathrm{HNO}_{3}$ \\
\hline & matter & $15 \mathrm{ml} \mathrm{H} \mathrm{H}_{2} \mathrm{O}$ & $20 \mathrm{ml}$ & $30 \mathrm{~min}$ & $85^{\circ} \mathrm{C}$ & 2 with $\mathrm{HNO}_{3}$ \\
\hline F8 & Residues & $\mathrm{H}_{2} \mathrm{O}$ pure & $10 \mathrm{ml}$ & & & \\
\hline
\end{tabular}

The partitioning of metals among the compartments of the sediment solid phase was investigated indirectly by selective sequential extractions (SSE), as described in Table 1. The SSE was performed with $1 \mathrm{~g}$ of ground sediment in 50 $\mathrm{ml}$ polypropylene centrifugation tubes to minimize losses of material. All extractions were performed in duplicate on three replications of each treatment. In each extraction series, a standard sample was introduced to follow the reproducibility of the procedure. After each extraction step, the tubes were centrifuged at $5200 \mathrm{rpm}$ for $20 \mathrm{~min}$. The supernatants were then filtered through $0.45 \mu \mathrm{m}$ membranes (Sartorius), whereas the residues were washed with $10 \mathrm{ml}$ of ultra-pure water, centrifuged again, and then the supernatants were pooled. The leachates (extract and rinsing) were stored in polypropylene bottles or glass vials at $4^{\circ} \mathrm{C}$ until chemical analysis. The residues were dried at $40^{\circ} \mathrm{C}$ prior to the next extraction step. Blanks without a sediment sample were used on each extraction step to determine the purity and quality of the procedure. The chemical forms were labelled according to the targeted geochemical compartments during each extraction step: F1 water soluble (WAT), F2 - exchangeable (EXCH), F3 - bound to carbonates (CAR), F4 - bound to Mn oxides (MNOX), F5 - bound to amorphous Fe oxides (FEOX1), F6 - bound to crystalline Fe oxides (FEOX2), F7 - associated with organics $(\mathrm{OM})$ and F8 - residual (RES). Each element in the different fractions was expressed as micrograms extracted per gram of soil and as a percentage of the total amount of metal extracted after the seven steps. The elements were analysed by ICP-MS.

\section{Results and discussion}

\subsection{Total HMs contents}

The results of total HMs content of every slice (TT-PX-1: 0 $20 \mathrm{~cm}$, TT-PX-2: $20-40 \mathrm{~cm}$, and TT-PX-3: $40-60 \mathrm{~cm}$ ) at 4 sample stations (P8 and P10: inside the baby clam breeding plain; P9: inside the harvested clam breeding plain; P11: on the frontier between the plains) are given in Table 2. These results are compared with the National Technical Regulation on Sediment Quality of Vietnam (QCVN 43:2012.BTNMT). This standard is the same with the standard given by Canadian sediment quality guidelines for the protection of aquatic life (CCME, 2003).

Table 2. HMs distribution in slices of sediment cores in the clam plains

\begin{tabular}{lrrrrrr} 
Name & $\mathrm{Cr}$ & $\mathrm{Zn}$ & $\mathrm{As}$ & $\mathrm{Cd}$ & $\mathrm{Hg}$ & $\mathrm{Pb}$ \\
\hline TT-P8-1 & 70.65 & 448.76 & 15.24 & 2.15 & 40.63 & 62.93 \\
TT-P8-2 & 62.39 & 620.40 & 35.99 & 5.95 & 34.87 & 77.18 \\
TT-P8-3 & 144.75 & 958.71 & 93.71 & .2 .00 & 17.21 & 103.76 \\
TT-P9-1 & 57.55 & 463.08 & 17.64 & 4.74 & 53.03 & 117.29 \\
TT-P9-2 & 66.10 & 439.20 & 13.27 & 3.05 & 120.37 & 61.45 \\
TT-P9-3 & 116.83 & 305.79 & 39.12 & 3.56 & 71.06 & 93.52 \\
TT-P10-1 & 67.52 & 374.75 & 13.70 & 1.80 & 86.76 & 60.74 \\
TT-P10-2 & 79.20 & 534.62 & 29.26 & 2.52 & 61.49 & 83.83 \\
TT-P10-3 & 87.91 & 568.31 & 19.46 & 3.18 & 40.07 & 47.37 \\
TT-P11-1 & 62.30 & 381.22 & 16.70 & 4.25 & 42.79 & 47.67 \\
TT-P11-2 & 63.23 & 423.68 & 27.26 & 2.79 & 36.82 & 43.22 \\
QCVN 43:2012/BTNMT & 160.00 & 271.00 & 41.60 & 4.20 & 0.70 & 112.00
\end{tabular}


Note: TT-PX-1: $0-20 \mathrm{~cm}, \pi-P X-2: 20-40 \mathrm{~cm}$, and TT-PX-3: $40-60 \mathrm{~cm}$; BDL: below detection limit

We have seen that contents of $\mathrm{Cr}, \mathrm{As}, \mathrm{Cd}$ and $\mathrm{Pb}$ were under the standard QCVN 43:2012/BTNMT, except at the depth $40-60 \mathrm{~cm}$ at TT-P8 where As concentration was exceeded 2.25 times. The concentrations of $\mathrm{Zn}$ were also found 1.12 - 3.53 times higher than the standard. They increased with depth at TT-P8, TT-P10, TT-P-11 and decreased with depth at TT-P9. Another HM, Hg, its concentration in the samples was 24.58 - 171.96 times higher than the standard and decreased with depth at TT-P8, TT-P10 and TT-P-11. The increase or decrease in $\mathrm{Zn}$ and Hg concentrations may be influenced by the activities of clams living in sediment.

\subsection{HMs in Selective Sequential Extraction}

\subsubsection{Cobalt (Co)}

The Co concentrations in the fractions at 4 sample stations are shown in Table 3.

Table 3. Co concentrations in the chemical fractions (per cent)

\begin{tabular}{|c|c|c|c|c|c|c|c|c|c|c|c|}
\hline Sample & $\begin{array}{r}\text { T- } \\
\text { P8-1 }\end{array}$ & $\begin{array}{r}\text { Tा- } \\
\text { P8-2 }\end{array}$ & $\begin{array}{c}\text { Tा- } \\
\text { P8-3 }\end{array}$ & $\begin{array}{c}\text { Tा- } \\
\text { P9-1 }\end{array}$ & $\begin{array}{r}\text { Tा- } \\
\text { P9-2 }\end{array}$ & $\begin{array}{r}\text { Tा- } \\
\text { P9-3 }\end{array}$ & $\begin{array}{r}\text { Tा- } \\
\text { P10-1 }\end{array}$ & $\begin{array}{r}\text { T- } \\
\mathrm{P} 10-2\end{array}$ & $\begin{array}{r}\text { T- } \\
\mathrm{P} 10-3\end{array}$ & $\begin{array}{r}\text { Tा- } \\
\mathrm{P} 11-1\end{array}$ & $\begin{array}{r}\text { Tा- } \\
\mathrm{P} 11-2\end{array}$ \\
\hline F1 & $\mathrm{BDL}$ & $\mathrm{BDL}$ & $\mathrm{BDL}$ & $\mathrm{BDL}$ & $\mathrm{BDL}$ & $\mathrm{BDL}$ & BDL & BDL & BDL & BDL & BDL \\
\hline $\mathrm{F} 2$ & 0.02 & 0.02 & 0.01 & 0.05 & 0.03 & 0.01 & 0.05 & 0.02 & 0.02 & 0.05 & 0.02 \\
\hline F3 & 3.17 & 1.44 & 0.79 & 5.79 & 5.86 & 2.73 & 5.91 & 3.96 & 1.75 & 3.59 & 2.47 \\
\hline $\mathrm{F} 4$ & 0.08 & 0.05 & 0.03 & 0.16 & 0.16 & 0.10 & 0.19 & 0.12 & 0.06 & 0.14 & 0.08 \\
\hline F5 & 2.84 & 1.55 & 0.81 & 3.88 & 3.81 & 2.33 & 4.01 & 3.19 & 1.42 & 3.41 & 2.37 \\
\hline F6 & 0.61 & 0.61 & 0.35 & 0.86 & 0.58 & 0.65 & 0.79 & 0.78 & 0.41 & 0.75 & 0.69 \\
\hline F7 & 87.4 & 91.87 & 91.63 & 83.09 & 83.16 & 89.65 & 82.56 & 87.04 & 91.19 & 85.55 & 88.65 \\
\hline F8 & 5.88 & 4.45 & 6.39 & 6.17 & 6.39 & 4.54 & 6.49 & 4.89 & 5.15 & 6.52 & 5.72 \\
\hline
\end{tabular}

Note: TT-PX-1: depth 0 - $20 \mathrm{~cm}$, TT-PX-2: depth $20-40 \mathrm{~cm}$, TT-PX-3: depth $40-60 \mathrm{~cm}$; BDL: below detection limit

The average distribution of Co in different chemical fractions by SSE procedure shows the following distribution (Table 3): F1 < F2 < F4 < F6 < F5 < F3 < F8 < F7. The highest concentration was found in F7 (oxidable fraction). The data more than $82 \%$ (82.5 - 91.9\%) shows an important role of organic matters in the oxidable condition at the surficial sediment layer. At this concentration, Co was a potential resource for the coastal estuary environment.

We found that the Co bound to carbonate (F3) decrease by the depth. The highest Co concentration/amount in the sediment layer $0-20 \mathrm{~cm}$ may due to the presence of clams. The Co amount accumulated in the carbonate shells after decomposition will be eventually released back into the environment. This Co amount has also the most ability to easily exchange with the environment and penetrate into the ecosystem.

In the F5 fraction, the Co concentration decreases also by the depth. This is in agreement with the results of Klinkhammer (1980) and Kumar and Edward (2009). The distribution of Co depends on the reduction-oxidation in the iron oxide phase. But in F7, the Co concentration increases by depth, which is related to the reduction of oxygen content by the depth of the sediment layers.

In the residue (F8), the distribution of Co is not clearly different at various depths. The amount of metal in this residue is difficult to separate from sediment, so the ability to enter the ecosystem is very low.

\subsubsection{Zinc (Zn)}

The $\mathrm{Zn}$ extractant in the fraction in Table 4 shows that the main distribution is in $\mathrm{F} 7$ and $\mathrm{F} 8$ with a rate of more than $97 \%$ of the total Zn content of all fractions. Accordingly, the distribution of $\mathrm{Zn}$ in the fractions increase as following: $\mathrm{F} 1$ $<\mathrm{F} 2<\mathrm{F} 4<\mathrm{F} 3<\mathrm{F} 6<\mathrm{F} 5<\mathrm{F} 8<\mathrm{F} 7$.

As we have known, Zn from the external environment enters the estuary area by some sources including wastewater (Boxall et al., 2000). The high content of Zncontaining organic matter present in this wastewater would lead to an increase in Zn concentration in the sediment. In addition, the $\mathrm{Zn}$ content present in the solid residue also indicates the level of $Z n$ contamination in the river system: the greater the percentage of HMs present in the solid residue, the lesser the pollution in the environment because this solid residue involves components that cannot be remobilized.

In the fraction $F$, the $\mathrm{Zn}$ distribution increases by the depth at position TT-P8, TT-P10 and TT-P11, and decrease at the position TT-P9 where clams were harvested over two months before sampling date. 
Table 4. Zn concentrations in the chemical fractions (per cent)

\begin{tabular}{|c|c|c|c|c|c|c|c|c|c|c|c|}
\hline $\begin{array}{l}\text { Sample } \\
\text { name }\end{array}$ & $\begin{array}{r}\text { T- } \\
\text { P8-1 }\end{array}$ & $\begin{array}{r}\text { T- } \\
\text { P8-2 }\end{array}$ & $\begin{array}{r}\text { T- } \\
\text { P8-3 }\end{array}$ & $\begin{array}{c}\text { T- } \\
\text { P9-1 }\end{array}$ & $\begin{array}{r}\text { T- } \\
\text { P9-2 }\end{array}$ & $\begin{array}{r}\text { Tा- } \\
\text { P9-3 }\end{array}$ & $\begin{array}{r}\text { Tा- } \\
\text { P10-1 }\end{array}$ & $\begin{array}{r}\text { TT- } \\
\text { P10-2 }\end{array}$ & $\begin{array}{r}\text { Tा- } \\
\text { P10-3 }\end{array}$ & $\begin{array}{r}\text { TT- } \\
\text { P11-1 }\end{array}$ & $\begin{array}{r}\text { Tा- } \\
\text { P11-2 }\end{array}$ \\
\hline F1 & $\mathrm{BDL}$ & $\mathrm{BDL}$ & $\mathrm{BDL}$ & $\mathrm{BDL}$ & $\mathrm{BDL}$ & 0.01 & BDL & 0.01 & 0.01 & BDL & 0.01 \\
\hline$F 2$ & 0.01 & $\mathrm{BDL}$ & BDL & 0.01 & 0.01 & 0.01 & 0.01 & 0.01 & 0.01 & 0.01 & 0.01 \\
\hline F3 & 0.19 & 0.10 & 0.09 & 0.21 & 0.25 & 0.53 & 0.25 & 0.17 & 0.12 & 0.21 & 0.21 \\
\hline F4 & 0.02 & 0.02 & 0.01 & 0.02 & 0.02 & 0.04 & 0.02 & 0.02 & 0.02 & 0.02 & 0.02 \\
\hline F5 & 0.70 & 0.43 & 0.23 & 0.62 & 0.45 & 1.03 & 0.81 & 0.63 & 0.43 & 0.77 & 0.66 \\
\hline F6 & 0.33 & 0.30 & 0.21 & 0.36 & 0.31 & 0.64 & 0.43 & 0.32 & 0.28 & 0.37 & 0.38 \\
\hline F7 & 74.41 & 82.65 & 86.16 & 77.59 & 69.06 & 67.29 & 74.23 & 81.85 & 81.59 & 75.77 & 78.77 \\
\hline F8 & 24.35 & 16.49 & 13.31 & 21.21 & 29.89 & 30.44 & 24.24 & 17.01 & 17.55 & 22.83 & 19.94 \\
\hline
\end{tabular}

Note: TT-PX-1: depth 0 - 20 cm, TT-PX-2: depth $20-40$ cm, TT-PX-3: depth $40-60$ cm; BDL: below detection limit

\subsubsection{Arsenic (As)}

Table 5 shows the arsenic distribution in fractions following the depth at the sample position. The increasing arsenic distribution in fractions is F2 $<$ F1 $<$ F4 $<$ F3 $<$ F6 $<$ F5 $<$ F7. The As concentrations in F8 are varying at different depths.

Table 5. As concentrations in the chemical fractions (per cent)

\begin{tabular}{|c|c|c|c|c|c|c|c|c|c|c|c|}
\hline $\begin{array}{l}\text { Sample } \\
\text { name }\end{array}$ & $\begin{array}{c}\text { Tा- } \\
\text { P8-1 }\end{array}$ & $\begin{array}{c}\text { Tा- } \\
\text { P8-2 }\end{array}$ & $\begin{array}{r}\text { T- } \\
\text { P8-3 }\end{array}$ & $\begin{array}{r}\text { T- } \\
\text { P9-1 }\end{array}$ & $\begin{array}{r}\text { T- } \\
\text { P9-2 }\end{array}$ & $\begin{array}{r}\text { Tा- } \\
\text { P9-3 }\end{array}$ & $\begin{array}{r}\text { Tा- } \\
\text { P10-1 }\end{array}$ & $\begin{array}{r}\text { Tा- } \\
\text { P10-2 }\end{array}$ & $\begin{array}{r}\text { TT- } \\
\text { P10-3 }\end{array}$ & $\begin{array}{r}\text { Tा- } \\
\text { P11-1 }\end{array}$ & $\begin{array}{r}\text { Tा- } \\
\text { P11-2 }\end{array}$ \\
\hline $\mathrm{F} 1$ & 0.03 & 0.01 & 0.01 & 0.02 & 0.03 & 0.01 & 0.03 & 0.02 & 0.02 & 0.02 & 0.01 \\
\hline $\mathrm{F} 2$ & 0.01 & 0.01 & $\mathrm{BDL}$ & 0.01 & 0.01 & 0.01 & 0.08 & 0.01 & 0.02 & $\mathrm{BDL}$ & $\mathrm{BDL}$ \\
\hline F3 & 0.32 & 0.14 & 0.06 & 0.30 & 0.46 & 0.17 & 0.50 & 0.24 & 0.35 & 0.30 & 0.18 \\
\hline F4 & 0.07 & 0.03 & 0.01 & 0.05 & 0.07 & 0.02 & 0.06 & 0.03 & 0.05 & 0.06 & 0.03 \\
\hline F5 & 7.36 & 2.53 & 0.74 & 7.56 & 9.38 & 2.17 & 12.23 & 5.32 & 3.67 & 7.94 & 2.77 \\
\hline F6 & 1.23 & 0.58 & 0.37 & 1.04 & 1.47 & 0.48 & 1.51 & 0.84 & 0.94 & 1.28 & 0.76 \\
\hline F7 & 90.97 & 89.37 & 84.51 & 88.29 & 88.56 & 94.61 & 85.60 & 93.54 & 86.93 & 90.39 & 96.24 \\
\hline F8 & BDL & 7.33 & 14.28 & 2.72 & BDL & 2.53 & BDL & BDL & 8.01 & BDL & BDL \\
\hline
\end{tabular}

Note: TT-PX-1: depth 0 - $20 \mathrm{~cm}$, TT-PX-2: depth $20-40 \mathrm{~cm}$, TT-PX-3: depth $40-60 \mathrm{~cm}$; BDL: below detection limit

The As content in fraction F7 is more than $84 \%$ of the total content of all fractions, even up to $96.2 \%$ at TT-P11 at depths of $20-40 \mathrm{~cm}$. This shows a close association of As with organic components in sediments. However, this distribution is very unstable by the depth: it decreases at position TT-P8, increases at position TT-P9 and position TT$\mathrm{P} 11$, increases in depth of $20-40 \mathrm{~cm}$, and then decreases at a depth of $40-60 \mathrm{~cm}$ for the sample at position TT-P10.

As shown in Table 5 for the arsenic content of F5 and F6, As also formed a relatively stable affinity for iron oxides. In particular, the association with amorphous Fe ranges from 0.74 to $12.2 \%$ depending on location and depth of sampling. Bounding with crystalline Fe only accounts for a very small proportion, $0.37-1.51 \%$. In F5, As tends to decrease by the depth at TT-P8, TT-P10 and TT-P11 positions, especially drastically reduced between the first two layers. At TT-P9, however, the As content was unstable, increasing in the second layer and decreasing sharply in the third layer. Similarly, the As content in F6 also tends to decrease with depth at TT-P8, TT-P10, and TT-P11 positions, and at TT-P9, As increases in the second layer then decreases rapidly in the third layer. Particularly in F8, at depth $0-20 \mathrm{~cm}$ at position TT-P8 and in the $20-40 \mathrm{~cm}$ depth layer at position TT-P9, at $0-20 \mathrm{~cm}$ and $20-40 \mathrm{~cm}$ layers of TT-P10 and $0-20 \mathrm{~cm}$ and $20-40 \mathrm{~cm}$ layers at position TT-P11 we do not see the presence of As.

\subsubsection{Cadmium (Cd)}

The $\mathrm{Cd}$ distribution in the fractions is $\mathrm{F} 1<\mathrm{F} 4<\mathrm{F} 2<\mathrm{F} 6=\mathrm{F} 5$ $=\mathrm{F} 3<\mathrm{F} 8<\mathrm{F} 7$ (Table 6). Cd is mainly present in fraction F7, more than 93.6\% (93.6 - 98.6\%) of total Cd content in sediment. This demonstrates the close association of $\mathrm{Cd}$ with the organic compounds present in the sediment. However, in F8 this content is only from 1.18 to $5.56 \%$, the highest at the depth $0-20 \mathrm{~cm}$ at TT-P8 and TT-P10 positions. This amount of $\mathrm{Cd}$ is very difficult to separate from sediment in order to get released into the surrounding environment. With F7, Cd increases with depth at TT-P8 and TT-P10 positions, gradually decreases at TT-P9 but is almost unchanged at TT-P11. But in F8, the $\mathrm{Cd}$ decreases at TT-P8 and TT-P10, increases at a depth of $20-40 \mathrm{~cm}$ at TT-P9 and is almost unchanged at TT-P11. 
Table 6. Cd concentrations in the chemical fractions (percent)

\begin{tabular}{|c|c|c|c|c|c|c|c|c|c|c|c|}
\hline $\begin{array}{l}\text { Sample } \\
\text { name }\end{array}$ & $\begin{array}{r}\text { Tा- } \\
\text { P8-1 }\end{array}$ & $\begin{array}{r}\text { Tा- } \\
\text { P8-2 }\end{array}$ & $\begin{array}{r}\text { Tा- } \\
\text { P8-3 }\end{array}$ & $\begin{array}{r}\text { T- } \\
\text { P9-1 }\end{array}$ & $\begin{array}{r}\text { Tा- } \\
\text { P9-2 }\end{array}$ & $\begin{array}{r}\text { Tा- } \\
\text { P9-3 }\end{array}$ & $\begin{array}{r}\text { Tा- } \\
\text { P10-1 }\end{array}$ & $\begin{array}{r}\text { Tा- } \\
\text { P10-2 }\end{array}$ & $\begin{array}{r}\text { Tा- } \\
\text { P10-3 }\end{array}$ & $\begin{array}{r}\text { Tा- } \\
\mathrm{P} 11-1\end{array}$ & $\begin{array}{r}\text { Tा- } \\
\mathrm{P} 11-2\end{array}$ \\
\hline F1 & $\mathrm{BDL}$ & $\mathrm{BDL}$ & $\mathrm{BDL}$ & $\mathrm{BDL}$ & BDL & $\mathrm{BDL}$ & BDL & 0.02 & 0.01 & 0.01 & BDL \\
\hline $\mathrm{F} 2$ & 0.02 & 0.01 & 0.01 & 0.04 & 0.02 & 0.02 & 0.04 & 0.05 & 0.03 & 0.02 & 0.04 \\
\hline F3 & 0.20 & 0.11 & 0.10 & 0.12 & 0.16 & 0.30 & 0.39 & 0.30 & 0.21 & 0.13 & 0.27 \\
\hline F4 & 0.02 & 0.01 & $\mathrm{BDL}$ & 0.01 & 0.01 & 0.03 & 0.01 & 0.02 & 0.01 & 0.01 & $\mathrm{BDL}$ \\
\hline F5 & 0.17 & 0.06 & 0.05 & 0.07 & 0.27 & 0.11 & 0.23 & 0.15 & 0.15 & 0.10 & 0.19 \\
\hline F6 & 0.17 & 0.06 & 0.03 & 0.07 & 0.10 & 0.12 & 0.19 & 0.17 & 0.15 & 0.07 & 0.18 \\
\hline F7 & 95.24 & 97.57 & 98.64 & 98.44 & 97.13 & 97.45 & 93.57 & 96.91 & 97.87 & 98.49 & 98.23 \\
\hline F8 & 4.18 & 2.18 & 1.17 & 1.26 & 2.30 & 1.96 & 5.56 & 2.38 & 1.57 & 1.17 & 1.07 \\
\hline
\end{tabular}

Note: TT-PX-1: depth $0-20 \mathrm{~cm}$, TT-PX-2: depth $20-40 \mathrm{~cm}, T$-PX-3: depth $40-60 \mathrm{~cm}$; BDL: below detection limit

\subsubsection{Mercury $(\mathrm{Hg})$}

As it can be observed in Table 7, there is no presence of $\mathrm{Hg}$ in the exchangeable fraction F2 and the Mn oxides F4.
The distribution of $\mathrm{Hg}$ increases in the fractions as following: $\mathrm{F} 1<\mathrm{F} 6<\mathrm{F3}<\mathrm{F5}<\mathrm{F} 8<\mathrm{F} 7$. Like other $\mathrm{HMs}, \mathrm{Hg}$ is predominantly present in the fraction F7, which accounts for more than $70 \%$ of the total. The amount of $\mathrm{Hg}$ in F8 also accounts for a relative proportion of $10.6-28.4 \%$.

Table 7. Hg concentrations in the chemical fractions (percent)

\begin{tabular}{|c|c|c|c|c|c|c|c|c|c|c|c|}
\hline $\begin{array}{l}\text { Sample } \\
\text { name }\end{array}$ & $\begin{array}{r}\text { TT- } \\
\text { P8-1 }\end{array}$ & $\begin{array}{r}\text { TT- } \\
\text { P8-2 }\end{array}$ & $\begin{array}{r}\text { TT- } \\
\text { P8-3 }\end{array}$ & $\begin{array}{r}\text { TT- } \\
\text { P9-1 }\end{array}$ & $\begin{array}{r}\text { TT- } \\
\text { P9-2 }\end{array}$ & $\begin{array}{r}\text { TT- } \\
\text { P9-3 }\end{array}$ & $\begin{array}{r}\text { TT- } \\
\text { P10-1 }\end{array}$ & $\begin{array}{r}\text { TT- } \\
\text { P10-2 }\end{array}$ & $\begin{array}{r}\text { TT- } \\
\text { P10-3 }\end{array}$ & $\begin{array}{r}\text { TT- } \\
\text { P11-1 }\end{array}$ & $\begin{array}{r}\text { TT- } \\
\text { P11-2 }\end{array}$ \\
\hline F1 & 0.02 & 0.01 & 0.00 & 0.01 & 0.01 & 0.01 & 0.01 & 0.02 & 0.01 & 0.01 & 0.01 \\
\hline $\mathrm{F} 2$ & $\mathrm{BDL}$ & $\mathrm{BDL}$ & $\mathrm{BDL}$ & $\mathrm{BDL}$ & $\mathrm{BDL}$ & $\mathrm{BDL}$ & $\mathrm{BDL}$ & $\mathrm{BDL}$ & $\mathrm{BDL}$ & $\mathrm{BDL}$ & $\mathrm{BDL}$ \\
\hline F3 & 0.20 & 0.24 & 0.37 & 0.18 & 0.09 & 0.17 & 0.34 & 0.60 & 1.27 & 0.15 & 0.19 \\
\hline F4 & $\mathrm{BDL}$ & $\mathrm{BDL}$ & $\mathrm{BDL}$ & $\mathrm{BDL}$ & $\mathrm{BDL}$ & $\mathrm{BDL}$ & $\mathrm{BDL}$ & $\mathrm{BDL}$ & $\mathrm{BDL}$ & $\mathrm{BDL}$ & $\mathrm{BDL}$ \\
\hline F5 & 0.25 & 0.25 & 0.47 & 0.24 & 0.11 & 0.17 & 0.19 & 0.19 & 0.25 & 0.30 & 0.28 \\
\hline F6 & 0.19 & 0.17 & 0.40 & 0.14 & 0.06 & 0.11 & 0.08 & 0.10 & 0.15 & 0.14 & 0.18 \\
\hline F7 & 88.71 & 81.72 & 70.38 & 83.55 & 88.02 & 85.32 & 81.83 & 83.30 & 79.69 & 81.90 & 77.58 \\
\hline F8 & 10.63 & 17.61 & 28.36 & 15.88 & 11.71 & 14.23 & 17.54 & 15.79 & 18.64 & 17.50 & 21.75 \\
\hline
\end{tabular}

Note: TT-PX-1: depth $0-20$ cm, TT-PX-2: depth $20-40$ cm, TT-PX-3: depth $40-60$ cm; BDL: below detection limit

\subsubsection{Lead $(\mathrm{Pb})$}

According to data shown in Table 8, $\mathrm{Pb}$ is completely absent in the water-soluble fraction F1 and fraction F2 and present with a negligible content in association with $\mathrm{Mn}$ oxides (F4). The distribution of $\mathrm{Pb}$ in fractions is as follows: $\mathrm{F} 3<\mathrm{F} 6=\mathrm{F} 5<\mathrm{F} 8<\mathrm{F} 7$. Similar to other metals, $\mathrm{Pb}$ is also found primarily in the oxidable fraction F7. In F8, Pb accounted for $8.61-20.0 \%$. At depths with F7, Pb increases at 20 - $40 \mathrm{~cm}$ layer at TT-P8 and TT-P10, while it decreases at the same layer at TT-P11 and TT-P9.

Table 8. $\mathrm{Pb}$ concentrations in the chemical fractions (percent)

\begin{tabular}{|c|c|c|c|c|c|c|c|c|c|c|c|}
\hline $\begin{array}{l}\text { Sample } \\
\text { name }\end{array}$ & $\begin{array}{r}\text { TT- } \\
\text { P8-1 }\end{array}$ & $\begin{array}{r}\text { T- } \\
\text { P8-2 }\end{array}$ & $\begin{array}{r}\text { T- } \\
\text { P8-3 }\end{array}$ & $\begin{array}{c}\text { Tा- } \\
\text { P9-1 }\end{array}$ & $\begin{array}{r}\text { T- } \\
\text { P9-2 }\end{array}$ & $\begin{array}{r}\text { Tा- } \\
\text { P9-3 }\end{array}$ & $\begin{array}{r}\text { Tा- } \\
\text { P10-1 }\end{array}$ & $\begin{array}{r}\text { Tा- } \\
\text { P10-2 }\end{array}$ & $\begin{array}{r}\text { TT- } \\
\text { P10-3 }\end{array}$ & $\begin{array}{r}\text { Tा- } \\
\mathrm{P} 11-1\end{array}$ & $\begin{array}{r}\text { Tा- } \\
\mathrm{P} 11-2\end{array}$ \\
\hline $\mathrm{F} 1$ & $\mathrm{BDL}$ & $\mathrm{BDL}$ & $\mathrm{BDL}$ & $\mathrm{BDL}$ & $\mathrm{BDL}$ & $\mathrm{BDL}$ & BDL & BDL & BDL & BDL & BDL \\
\hline $\mathrm{F} 2$ & $\mathrm{BDL}$ & $\mathrm{BDL}$ & BDL & $\mathrm{BDL}$ & BDL & $\mathrm{BDL}$ & $\mathrm{BDL}$ & $\mathrm{BDL}$ & $\mathrm{BDL}$ & $\mathrm{BDL}$ & $\mathrm{BDL}$ \\
\hline F3 & 0.33 & 0.37 & 0.49 & 0.15 & 0.28 & 0.79 & 0.23 & 0.49 & 0.84 & 0.13 & 0.71 \\
\hline F4 & $\mathrm{BDL}$ & 0.01 & $\mathrm{BDL}$ & $\mathrm{BDL}$ & BDL & 0.01 & $\mathrm{BDL}$ & BDL & 0.01 & $\mathrm{BDL}$ & 0.01 \\
\hline F5 & 1.06 & 0.73 & 0.46 & 0.64 & 1.18 & 0.48 & 0.94 & 0.56 & 0.89 & 1.35 & 1.18 \\
\hline F6 & 0.98 & 0.79 & 0.86 & 0.67 & 0.93 & 1.34 & 1.30 & 0.91 & 1.21 & 1.28 & 1.20 \\
\hline F7 & 83.14 & 86.68 & 83.10 & 89.93 & 82.50 & 88.13 & 82.74 & 88.68 & 77.03 & 83.14 & 81.24 \\
\hline F8 & 14.48 & 11.43 & 15.08 & 8.61 & 15.10 & 9.25 & 14.78 & 9.36 & 20.03 & 14.1 & 15.66 \\
\hline
\end{tabular}

Note: TT-PX-1: depth $0-20 \mathrm{~cm}$, TT-PX-2: depth $20-40 \mathrm{~cm}$, TT-PX-3: depth $40-60 \mathrm{~cm}$; BDL: below detection limit

\subsubsection{Chromium (Cr)}

$\mathrm{Cr}$ concentration is distributed in the fractions of the sediment sample in the following order: F1 <F3 <F5 <F6 $<F 8<F 7$ and is completely absent in phase F2 and F4 with all samples analyzed. More than $62 \%$ of $\mathrm{Cr}$ is concentrated in fraction F7. This is the amount of $\mathrm{Cr}$ in the sediment sample that is likely to be involved in oxidation reactions. $\mathrm{Cr}$ content in F8 with a high ratio of 20.9 - 38.4\% is hardly separable from sediment materials to participate in the environment. The rate of $\mathrm{Cr}$ present in the fraction F5 and 
F6 is quite low, accounting for less than $2 \%$ of the total $\mathrm{Cr}$ content in sediment samples.

Table 9. Cr concentrations in the chemical fractions (percent)

\begin{tabular}{|c|c|c|c|c|c|c|c|c|c|c|c|}
\hline $\begin{array}{l}\text { Sample } \\
\text { name }\end{array}$ & $\begin{array}{r}\text { T- } \\
\text { P8-1 }\end{array}$ & $\begin{array}{r}\text { T- } \\
\text { P8-2 }\end{array}$ & $\begin{array}{r}\text { T- } \\
\text { P8-3 }\end{array}$ & $\begin{array}{r}\text { Tा- } \\
\text { P9-1 }\end{array}$ & $\begin{array}{r}\text { Tा- } \\
\text { P9-2 }\end{array}$ & $\begin{array}{r}\text { Tा- } \\
\text { P9-3 }\end{array}$ & $\begin{array}{r}\text { Tा- } \\
\text { P10-1 }\end{array}$ & $\begin{array}{r}\text { Tा- } \\
\text { P10-2 }\end{array}$ & $\begin{array}{r}\text { Tा- } \\
\text { P10-3 }\end{array}$ & $\begin{array}{r}\text { Tा- } \\
\text { P11-1 }\end{array}$ & $\begin{array}{r}\text { Tा- } \\
\text { P11-2 }\end{array}$ \\
\hline $\mathrm{F} 1$ & $\mathrm{BDL}$ & $\mathrm{BDL}$ & $\mathrm{BDL}$ & $\mathrm{BDL}$ & $\mathrm{BDL}$ & $\mathrm{BDL}$ & BDL & $\mathrm{BDL}$ & BDL & BDL & BDL \\
\hline $\mathrm{F} 2$ & BDL & $\mathrm{BDL}$ & BDL & $\mathrm{BDL}$ & BDL & BDL & 0.01 & $\mathrm{BDL}$ & BDL & $\mathrm{BDL}$ & BDL \\
\hline F3 & 0.59 & 0.56 & 0.29 & 0.76 & 0.63 & 0.39 & 0.62 & 0.65 & 0.51 & 0.74 & 0.72 \\
\hline F4 & BDL & $\mathrm{BDL}$ & BDL & BDL & $\mathrm{BDL}$ & $\mathrm{BDL}$ & BDL & $\mathrm{BDL}$ & BDL & BDL & BDL \\
\hline F5 & 1.40 & 1.62 & 0.74 & 1.90 & 1.57 & 0.96 & 1.55 & 1.23 & 1.25 & 1.57 & 1.48 \\
\hline F6 & 1.43 & 1.77 & 1.17 & 1.94 & 1.62 & 1.06 & 1.64 & 1.46 & 1.36 & 1.694 & 1.77 \\
\hline F7 & 58.09 & 62.98 & 64.16 & 68.21 & 70.01 & 62.05 & 63.46 & 75.78 & 69.15 & 71.32 & 75.11 \\
\hline F8 & 38.49 & 33.07 & 33.64 & 27.19 & 26.16 & 35.53 & 32.72 & 20.88 & 27.73 & 24.67 & 20.92 \\
\hline
\end{tabular}

Note: TT-PX-1: depth 0 - $20 \mathrm{~cm}, \pi$ T-PX-2: depth $20-40 \mathrm{~cm}$, TT-PX-3: depth $40-60 \mathrm{~cm}$; BDL: below detection limit

\section{Conclusions}

The concentration of total HMs in sediment cores in comparison with the standard QCVN 43:2012/BTNMT shows a pollution with $\mathrm{Zn}$ and $\mathrm{Hg}$ whose concentrations are 1.12 - 3.53 times and 24.6 - 171 times higher than the standard. The average distribution pattern of HMs in different SSE fractions increases in the order of F1<F2<F4< F3 $<$ F6 $<$ F5 $<$ F8 $<$ F7. The highest concentration of heavy metals was found in the oxidable and residual phases. The data more than $60 \%$ shows that most of HMs seem to be available for the biological activities in the oxidable condition at the surficial sediment layer. The heavy metal concentrations depending on the depth of sediment show that clam's digestive activity or the decomposition of tissue and shell of clams possibly affects the content of heavy metals.

Acknowledgments. I would like to express my sincere thanks to The National Foundation for Science and Technology Development (NAFOSTED), affiliated with the Ministry of Science and Technology (MOST) for their precious financial support; without this, my research (project code: 105.99-2010.17) cannot be completed. My special thanks are devoted to Dr. Nguyen Van Thuyen from the University of Natural Sciences, Vietnam for his endless support in the field trip. Last but not least, I would like to thank my colleagues working at the Institute of Geological Science (IGS) of the Vietnam Academy of Science and Technology (VAST), who often helped and gave me valuable support at critical junctures in terms of experiments during the making to this research.

\section{References}

[1] Ahumuda, I., Mendoza, J., Navarrete, E. and Ascar, L. 1999. Sequential extraction of heavy metals in soils irrigated with wastewater. Commun. Soil Sci. Plant Anat. 30(9-10), 1507-1519.

[2] Bao Moi (2013) White dead clams in Go Cong (in Vietnamese). Retrieved from https://baomoi.com/ngheuchet-trang-o-xu-go-cong/c/10586760.epi.
[3] Beijer, K. and Jernelov A. 1986. Sources, transport and transformation of metals in the environment. In L. Friberg, G.F. Nordberg, and V.B. Vouk (Eds.), Handbook on the toxicology of metals. Amsterdam: Elsevier, 68-84.

[4] Boxall, A. B. A., Comber, S. D., Conrad, A. U., Howcroft, J. and Zaman, N. 2000. Inputs, monitoring and fate modeling of antifouling biocides in UK estuaries. Mar. Poll. Bull., 40(11), 898-905.

[5] CCME - Canadian Council of Ministers of the Environment (2013). Canadian environmental quality guidelines for the protection of aquatic life (retrieved from http://cegg-rcqe.ccme.ca/download/en/221).

[6] Forstner, U., 1989. Contaminated Sediment. Lectures on Environmental Aspects of Particle-Associated Chemicals in Aquatic Systems. Springer-Verlag Berlin Heidelberg. ISBN 978-3-540-51076-5.

[7] lyengar, S. S., Martens, D. C. and Miller, W. P. 1981. Distribution and plant availability of soil zinc fractions. Soil Sci. Soc. Am. J. 45(4), 735-739.

[8] Jarvis, K.E., Gray, A. L., Houk, R.S. 1992. Handbook of Inductively Coupled Plasma Mass Spectrometry. Blackie, Glasgow, 172-224. ISBN 978-94-010-5355-6.

[9] Klinkhammer G. P. 1980. Early diagenesis in sediments from the eastern equatorial pacific II. Porewater metal results. Earth and Planet Sci. Lett., 49(1), 81101.

[10] Kumar, S. P. and Edward J. K. P. 2009. Assessment of metal concentration in the sediment cores of Manakudy estuary, south west coast of India. Indian Journal of Marine sciences, 38 (2), 235-248.

[11] Leleyter, L. and Probst, J.-L. 1999. A new sequential extraction procedure for the speciation of particulate trace elements in the river sediments. J. Environ. Anal. Chem. 73(2), 109-128.

[12] Loska, K. and Wiechula, D., 2002. Speciation of Cd in the bottom sediments of Rubnik reservoir. Water, Air and Soil Pollution 141(1-4), 73-89. 
[13] MOFI - Ministry of Fisheries, 2006. Review of 2005 state plan implementation and orientation and task for Socio - Economic development in 2006 of fisheries sector. Vietnam, Ministry of Fisheries, 25pp.

[14] Morris, A. W., Allen, J. I., Howland, R. J. M., Wood, R. G., 1995. The estuary plume zone: source or sink for land derived nutrient discharges? Estuarine, Coastal and Shelf Science. 40(4), 387-402.

[15] Nhan Dan (2011) Worries in the oyster season in Tien Giang (in Vietnamese). Retrieved from http://www.nhandan.com.vn/xahoi/item/15887302.html.

[16] Nong Nghiep (2010) Tien Giang: helpless looking at dead clam (in Vietnamese). Retrieved from https://nongnghiep.vn/tien-giang-bat-luc-nhinngheu-chet-post46684.html.
[17] Salomons, W. and Forstner, U., 1984. Metals in the hydrocycle. Springer-Verlag Berlin Heidelberg, Germany. ISBN 978-3-642-69325-0.

[18] Schuman, L. M. 1985. Fractionation methods for soil microelements. Soil Sci. 140(1), 11-22.

[19] Tessier, A., Campbell, P. G. C. and Bisson, M. 1979. Sequential extraction procedure for the speciation of trace metals. Analytical Chemistry 51(7), 844-851.

[20] Vollenweider, R.A., Rinaldi, A., Viviani, R., Todini, E. 1996. Assessment of the state of eutrophication in the Mediterranean Sea. MAP Technical Reports Series No. 106. UNEP, Athens, 211 pp.

[21] Zing (2013) 1,400 hectares of oysters in Tien Giang suddenly die... clean (in Vietnamese). Retrieved from https://news.zing.vn/1400ha-ngheu-tai-tien-giangbong-dung-chet-sach-post308277.html. 